\title{
IMPLEMENTASI STRATEGI PEMBELAJARAN BERCERITA DI KELOMPOK B TK PATRIOTIK KECAMATAN SUWAWA KABUPATEN BONE BOLANGO
}

\author{
Rapi Us. Djuko \\ (Dosen PG-PAUD FIP UNG)
}

\begin{abstract}
ABSTRAK
Sebelum melaksanakan kegiatan bercerita, guru terlebih dahulu menetapkan rancangan prosedur/langkah-langkah yang harus dilalui dalam bercerita, berikut ini akan diuraikan langkah-langkah yang harus ditempuh oleh guru dalam menerapkan kegiatan bercerita dikelas. Meliputi : (1) menetapkan tujuan dan tema cerita; (2) menetapkan bentuk bercerita yang dipilih; (3) menetapkan bahan dan yang digunakan dalam kegiatan bercerita; (4) menetapkan rancangan langkah-langkah kegiatan bercerita, antara lain mengkomunikasikan tujuan dan tema cerita, mengatur tempat duduk kegiatan pembukaan, pengembangan cerita, menetapkan tehnik bertutur yang akan digunakan, dan mengajukan pertanyaan-pertanyaan menyangkut isi cerita; (5) menetapkan rancangan penilaian kegiatan bercerita. Rancangan penilaian ini mengacu pada rancangan pelaksanaan kegiatan, serta tujuan dan tema yang telah dipilih sebelumnya, tanggapan dan jawaban mereka merupakan petunjuk atas pemahaman mereka tentang isi cerita. Kelima langkah kegiatan bercerita ini telah dilaksanakan oleh guru di kelompok B TK Patriotik dalam mengembangkan kemampuan berbahasa khususnya bercerita, dengan memanfaatkan buku-buku di sekolah sebagai media bercerita pada anak. Disamping itu media gambar juga paling efektif sebagai media penyampai cerita pada anak.
\end{abstract}

Kata Kunci : Strategi bercerita, Kemampuan Bahasa (bercerita) 


\section{A.PENDAHULUAN}

Anak usia dini merupakan generasi penerus bangsa di masa yang akan datang. Anak dilahirkan dengan potensi dan kecerdasannya masingmasing. Untuk mengoptimalkan potensi anak, orang dewasa dan lingkungan di sekitar anak harus dapat memberikan stimulasi yang tepat dan sesuai dengan kebutuhan dan tahapan perkembangan anak. Anak harus diberikan kesempatan untuk berkreasi serta berimajinasi, agar anak dapat tumbuh dan berkembang dengan optimal. Salah satu ciri anak yang tumbuh dan berkembang dengan baik adalah, mereka mampu beradaptasi dengan lingkungannya, mampu berkomunikasi dan berinteraksi dengan orang lain, serta berani dalam bertindak.

Banyak cara yang dapat dilakukan agar tumbuh kembang anak khususnya aspek bahasa, dapat berkembang seiring dengan tahap perkembangannya. Salah satunya adalah melalui bercerita. Bercerita dapat menjadi cara bagi orang tua dan guru untuk memberikan contoh atau model pembelajaran kepada anak melalui cerita yang dibacakan untuk anak. Bercerita juga dapat memberikan kesempatan bagi anak untuk tampil di depan teman maupun orang lain.

Metode bercerita merupakan salah satu metode yang banyak dipergunakan di Taman Kanak-kanak. Metode bercerita merupakan salah satu strategi pembelajaran yang dapat memberikan pengalaman belajar bagi anak TK. Cerita yang dibawakan guru secara lisan harus menarik, dan mengundang perhatian anak dan tidak lepas dari tujuan pendidikan bagi anak TK.

Berbagai jenis tehnik bercerita yang dapat digunakan guru untuk menerapkan strategi pembelajaran bercerita di kelas, seperti membaca langsung dari buku cerita, bercerita menggunakan boneka tangan, gambar seri, bercerita menggunakan papan flannel, bermain peran mikro/makro, bercerita sambil memainkan jari-jari tangannya, menggunakan panggung boneka, dan bercerita menggunakan iliustrasi gambar dari buku. 
Demikian pula halnya metode bercerita ini dalam perkembangan bahasa anak usia dini mengembangkan kemampuan khususnya kemampuan berbicara. berbicara anak.

Guru sebagai satu-satunya unsur yang bertanggung jawab di kelas terhadap perkembangan kemampuan ini harus memiliki berbagai cara atau trik untuk mestimulasi perkembangan berbicara anak. Salah satunya adalah dengan menggunakan metode bercerita.

Metode bercerita merupakan salah satu pemberian pengalaman belajar bagi anak TK dengan membawakan cerita kepada anak secara lisan (dalam Moeslichatoen, 2004, 157). Selanjutnya menurut beliau bahwa cerita yang dibawakan guru harus menarik, dan mengundang perhatian anak dan tidak lepas dari tujuan pendidikan bagi anak TK.

Kurang optimalnya metode ini diterapkan guru dalam pembelajaran akan berdampak pada kemampuan berbicara anak, baik perbendaharaan kosa kata, kemampuan menjawab pertanyaan, kemampuan memberikan pendapat/ide, akan rendah pula. Oleh karena itu, penelitian ini bermaksud untuk melihat sejauh mana penerapan

\section{B.LANDASAN TEORI
1. Pengertian Strategi Pembelajaran

Westphal (1979: 120) yang dikutip oleh Tarigan (1989: 7) memberi batasan istilah-istilah silabus, pendekatan (approach), strategi dan metode sebagai berikut: silabus mengacu kepada isi pokok bahasan suatu pelajaran atau rangkaian pelajaran serta urutan penyajiannya; pendekatan secara ideal merupakan dasar teoritis yang menentukan caracara memperlakukan atau membicarakan silabus; strategi/teknik adalah kegiatan instruksional pribadi seperti yang terjadi di dalam kelas; metode merupakan gabungan ketiga faktor di atas, walaupun beberapa kombinasi memperlihatkan kesamaan yang nyata dalam tujuan pelajaran daripada yang lain-lainnya. Ketiga unsur tersebut (silabus, pendekatan, strategi/teknik) digabung dengan test aktual dan bahan pengajaran terpilih 
serta gaya pribadi sang guru, dapat dikatakan membangun suatu metode yang utuh. Dengan perkataan lain, istilah metode seperti yang dimaksudkan disini mengimplementasikan suatu hierarki prioritas yang disusun oleh sang guru atau sang perencana.

Khususnya pada strategi pembelajaran, dalam setiap kegiatan yang dilakukan guru, harus mempertimbangkan secara cermat strategi apa yang akan digunakan untuk memudahkan anak belajar. Strategi pembelajaran ini sangat beraneka ragam dalam bentuk kegiatan, tingkat formalitas, tingkat kesulitan dan pola kegiatannya.

\section{Jenis-jenis}

Strategi

Pembelajaran di Taman

\section{Kanak-kanak}

Menurut Koestelnik (1999) yang dikutip Masitoh (2005) bahwa, terdapat berbagai strategi pembelajaran umum yang dapat digunakan di lembaga-lembaga pendidikan anak usia dini umumnya dan anak Taman Kanak-kanak khususnya. Strategi pembelajaran umum tersebut adalah: 1) meningkatkan keterlibatan indera; 2) mempersiapkan isyarat lingkungan; 3) analisis tugas; 4) bantuan orang yang lebih berpengalaman (scaffolding); 5) praktek terbimbing; undangan/ajakan; 7) refleksi tingkah laku; 8) refleksi kalimat; 9) contoh atau modelling; 10) penghargaan efektif; 11) menceritakan/ menjelaskan/ menginformasikan; 12) do-it-signal; 13) tantangan; 14) pertanyaan, dan 15) kesenyapan.

Mengacu pada strategi pembelajaran umum, selanjutnya Kostelnik (1999) mengemukakan tujuh jenis strategi pembelajaran khusus yang dapat dijadikan dasar untuk merencanakan dan melaksanakan kegiatan pembelajaran pada pendidikan anak usia dini umumnya dan anak Taman Kanak-kanak khususnya. Strategi pembelajaran ini relevan untuk digunakan pada anakanak yang berusia 3-8 tahun. Jenisjenis strategi pembelajaran khusus tersebut adalah: a) kegiatan eksploratori (exploratory activities); b) penemuan terbimbing (guided 
discovery); c) pemecahan masalah (problim solving); d) diskusi (discussion); e) belajar kooperatif (cooperative learning); f) demonstrasi (demonstration); g) pengajaran langsung (direct instruction).

\section{Kegiatan Eksploratori.}

Menurut Tylor (1993) yang dikutip Masitoh dkk bahwa, kegiatan eksploratori memungkinkan anak untuk mengembangkan penyelidikan langsung melalui langkah-langkah spontan, belajar membuat keputusan tentang apa yang dilakukan, bagaimana cara melakukannya, dan kapan melakukannya. Melalui kegiatan eksploratori anak-anak menemukan sesuatu yang berhubungan dengan dirinya sendiri dan memilih kegiatan yang sesuai dengan minatnya. Dalam kegiatan ini anak mengambil prakarsa untuk melakukan kegiatan.

\section{Penemuan Terbimbing.}

Tujuannya adalah agar anak-anak dapat membuat hubungan dan membangun konsep melalui interaksi dengan benda dan manusia. Guru harus merencanakan pengalaman bagi anak agar mereka dapat menemukan sesuatu. Peranan anak adalah membangun pengetahuan bagi dirinya sendiri, membuat pilihan dan keputusan, melakukan percobaan, mengalami, memunculkan pertanyaan dan menemukan jawabannya. Peranan guru adalah untuk menyediakan alat dan informasi yang diperlukan, yang dapat mendukung kemajuan belajar anak melalui pengembangan kemampuan yang berkaitan.

\section{Pemecahan}

Masalah.

Melalui strategi ini anak-anak merencanakan, meramalkan, mengamati hasil-hasil tindakannya dan merumuskan kesimpulan dari hasilhasil tindakannya. Peranan guru adalah sebagai fasilitator. Masalah-masalah yang paling baik untuk dipecahkan anak-anak adalah tentang hal-hal yang berkaitan dengan dirinya melalui berbagai cara, memberikan peluang kepada mereka untuk mengumpulkan informasi yang konkret dan mengandung lebih dari satu kemungkinan untuk memecahkannya.

Diskusi. Metode diskusi adalah salah satu strategi pembelajaran yang menunjukkan interaksi timbal balik 
atau berbalas-balasan antara guru dengan anak; guru berbicara kepada anak; anak berbicara kepada guru; dan anak berbicara kepada anak lainnya. Peran guru dalam strategi diskusi tidak membimbing percakapan anak-anak, akan tetapi mendorong mereka untuk mengemukakan gagasannya sendiri, dan mengomunikasikannya serta mengembangkan gagasan tersebut secara lebih luas kepada orang lain, yaitu teman-teman atau gurunya.

Belajar Kooperatif. Salah satu hal yang memberikan kemudahan bagi guru untuk mengembangkan strategi ini adalah karena pada anak-anak usia TK aspek perkembangan sosialnya sedang berkembang dengan pesat. Mereka senang berteman, bermain bersama, dan bekerja dalam kelompok kecil. Dalam menggunakan strategi belajar kooperatif guru menekankan peningkatan aspek keterampilan sosial meliputi hal-hal memahami tugas, mendengarkan orang lain sebagai pasangan atau teman, memanggil pasangan dengan namanya, berbicara dengan kata-kata yang sopan, mengambil giliran, menawarkan bantuan, dan menghargai orang lain.

Demonstrasi. Merupakan strategi pembelajaran yang dilaksanakan dengan cara memperlihatkan bagaimana proses terjadinya atau cara bekerjanya sesuatu dan bagaimana tugas-tugas itu dilaksanakan. Ketika guru mendemonstrasikan sesuatu, arah kegiatan juga diberikan kepada anak. Yang perlu diperlihatkan guru ketika mendemonstrasikan sesuatu, adalah ia harus melakukan pengamatan terhadap kegiatan yang dilaksanakan anak-anak didiknya.

\section{Pengajaran}

Langsung.

Strategi ini lebih dari sekedar menceritakan atau menunjukan sesuatu yang sederhana kepada anak, tetapi merupakan gabungan dari modeling, analisis tugas, penghargaan yang efektif, menginformasikan, do-it-signal, dan tantangan. Supaya lebih menarik perhatian anak-anak, pengajaran langsung harus dilengkapi dengan teknik-teknik yang menarik pula misalnya menggunakan gerak tubuh, ekspresi dan mimik wajah yang sesuai 
dengan hal yang sedang disajikan, membuat kesalahan yang disengaja sebagai humor, kejutan-kejutan dan kesungguhan atau antusiasme guru.

\section{Implementasi Strategi} Pembelajaran Bercerita

Penggunaan bercerita sebagai salah satu strategi pembelajaran di Taman Kanak-kanak haruslah memperhatikan hal-hal berikut: (a) isi cerita harus terkait dengan dunia kehidupan anak TK, sehingga mereka dapat lebih memahami dan dapat menangkap isi cerita tersebut, karena membahas mengenai hal-hal yang tidak asing bagi mereka; (b) kegiatan bercerita diusahakan dapat memberikan perasaan gembira, lucu, dan mengasyikan sesuai dengan dunia kehidupan anak yang penuh suka cita; (c) kegiatan bercerita harus diusahakan menjadi pengalaman bagi anak TK yang bersifat unik dan menarik, yang menggetarkan perasaan anak, serta dapat memotivasi anak untuk mengikuti cerita itu sampai tuntas.

Menurut Masitoh dkk (2005), sebelum melaksanakan kegiatan bercerita, guru harus terlebih dahulu menetapkan

rancangan

prosedur/langkah-langkah yang harus dilalui dalam bercerita. Berikut ini akan diuraikan langkah-langkah yang harus ditempuh guru dalam menerapkan kegiatan bercerita di kelas. Meliputi: (1) menetapkan tujuan dan tema cerita. Contoh: Tujuan: Menanamkan kebiasaan hidup hemat dan tolong menolong sesama teman. Tema: Menabung. Selanjutnya guru mulai mempelajari isi cerita, memahami urutan cerita serta perwatakan tokoh-tokoh yang ada dalam cerita tersebut; (2) menetapkan bentuk bercerita yang dipilih. Misalnya, bercerita dengan membaca langsung dari buku cerita, menggunakan ilustrasi gambar, menggunakan papan flanel, menceritakan dongeng, dan sebagainya. Untuk tema cerita menabung ini, dipilih bentuk bercerita dengan membaca buku cerita. Guru harus dapat memilih buku cerita yang sesuai dengan tujuan dan tema yang telah dipilih sebelumnya; (3) menetapkan bahan dan alat yang diperlukan dalam kegiatan bercerita. Sesuai dengan 
bentuk bercerita yang telah dipilih yakni bercerita dengan membaca buku, maka guru menyiapkan buku yang sesuai dengan tema cerita serta memperlihatkan pada anak gambargambar yang ada pada buku tersebut; (4) menetapkan rancangan langkahlangkah kegiatan bercerita, antara lain: mengkomunikasikan tujuan dan tema cerita, mengatur tempat duduk, kegiatan pembukaan, pengembangan cerita, menetapkan teknik bertutur yang akan digunakan, dan mengajukan pertanyaan-pertanyaan yang berkaitan dengan isi cerita; (5) menetapkan rancangan penilaian kegiatan bercerita. Rancangan penilaian ini mengacu pada rancangan pelaksanaan kegiatan, serta tujuan dan tema yang telah dipilih sebelumnya. Berkenaan dengan tema menabung, guru dapat menggali pengalaman anak berkaitan dengan kebiasaan anak dalam menabung atau apa yang akan mereka lakukan dengan uang tabungan mereka serta apa yang akan mereka lakukan jika menemui orang yang dalam kesulitan serta membutuhkan uang segera. Tanggapan dan jawaban mereka merupakan petunjuk atas pemahaman mereka atas isi cerita.

Berdasarkan kajian teori-teori di atas, maka yang dimaksud dengan kegiatan bercerita dalam penelitian ini adalah: suatu cara pencapaian kompetensi melalui penceritaan yang disampaikan oleh guru secara lisan kepada anak dengan memperhatikan kriteria bercerita yang baik, meliputi: pemilihan tempat bercerita, mengatur posisi duduk siswa, bahasa cerita, intonasi guru, pemunculan tokohtokoh, penampakkan emosi, peniruan suara, penguasaan terhadap siswa yang tidak serius, dan menghindari ucapan yang spontan.

\section{C.PEMBAHASAN}

Implementasi strategi pembelajaran bercerita pada kelompok B dapat dilakukan dengan menggunakan beberapa langkah yang terdiri dari :

\section{Menetapkan Tujuan Dan Tema} Cerita.

Sesuai hasil wancara dengan informan bahwa penetapan tujuan dan tema bercerita sudah dilakukan 
terlebih dahulu mengacu kepada RPPM dan RPPH yang sudah ditetapkan. Tema yang seringkali disukai anak-anak adalah cerita tentang binatang. Namun kadangkadang untuk menarik minat anak terhadap pembelajaran pada hari itu, guru mengangkat cerita lain untuk diceritakan walaupun di luar dari tema yang akan dilaksanakan pada hari itu.

Guru sebagai pelaksana pembelajaran di kelas yang telah memilih dan menetapkan strategi pembelajaran melalui bercerita untuk menyampaikan materi pembelajaran sesuai tema yang berlaku pada hari itu, selanjutnya guru mulai mempelajari isi cerita, memahami urutan cerita serta perwatakan tokoh-tokoh yang ada dalam cerita tersebut agar dengan mudah dia menceritakan cerita tersebut dan anak-anak juga tertarik mendengarkan cerita

\section{Menetapkan Bentuk Bercerita Yang Dipilih.}

Salah satu bentuk bercerita yang dipilih misalnya, bercerita dengan membaca langsung dari buku cerita, menggunakan ilustrasi gambar, menggunakan papan flanel, menceritakan dongeng, dan sebagainya. Guru harus dapat memilih buku cerita yang sesuai dengan tujuan dan tema yang telah dipilih sebelumnya.

Hasil wawancara dengan beberapa informan, diperoleh informasi bahwa, tehnik bercerita yang lebih banyak disukai anak adalah dengan memadukan dua tehnik sekaligus yaitu bercerita menggunakan buku cerita bergambar. Dengan melihat gambar dalam cerita itu, anak menjadi lebih fokus dan perhatian kepada cerita yang diceritakan guru dibandingkan apabila guru hanya membaca cerita dari buku. Perbendaharaan kosa kata anak menjadi lebih terbangun dengan adanya gambar-gambar dalam cerita tersebut. Mereka bertanya, mengemukakan pendapat, berargumentasi dan membuat sinkronisasi dengan kejadian-kejadian yang mereka alami di lingkungan sekitarnya, baik dalam lingkungan keluarga maupun lingkungan masyarakat yang selama ini menjadi 
sumber belajar yang tersedia luas bagi pembelajaran anak usia dini.

\section{Menetapkan Bahan Dan Alat} Yang Diperlukan Dalam Kegiatan Bercerita.

Sesuai dengan bentuk bercerita yang telah dipilih yakni bercerita dengan membaca buku, maka guru menyiapkan buku yang sesuai dengan tema cerita serta memperlihatkan pada anak gambar-gambar yang ada pada buku tersebut.

Berdasarkan hasil wawancara dengan beberapa informan dapat diperoleh informasi bahwa, dalam rangka menyiapkan bahan dan alat yang diperlukan dalam kegiatan bercerita, mereka memanfaatkan perpustakaan sekolah untuk memperoleh buku cerita yang sesuai dngan tema yang akan diajarkan pada hari itu. Namun apabila mereka menemukan kendala, mereka akan berusaha memperolehnya dari sumbr lain yang terdekat. Demikian pula halnya dengan media gambar yang akan digunakan, mereka berusaha untuk mengadakannya dengan cara di

scan gambar tersebut kemudian diperbesar lalu diprint out hasilnya.

4. Menetapkan

Langkah-Langkah

\section{Bercerita}

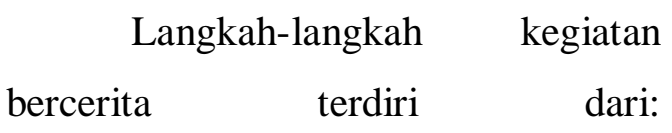
mengkomunikasikan tujuan dan tema cerita, mengatur tempat duduk, kegiatan pembukaan, pengembangan cerita, menetapkan teknik bertutur yang akan digunakan, dan mengajukan pertanyaan-pertanyaan yang berkaitan dengan isi cerita.

Sesuai hasil wawancara dengan beberapa informan, diperoleh informasi bahwa: enam langkah kegiatan bercerita yang terdiri dari mengkomunikasikan tujuan dan tema, mengatur tempat duduk anak, pembukaan kegiatan bercerita, pengembangan cerita yang dituturkan guru, bertutur yang dapat menggetarkan hati anak dan penutup kegiatan bercerita, dapat mereka laksanakan dengan baik walaupun masih terdapat kekurangannya. Namun mereka berusaha meminimalisir 
kekurangan tersebut demi sudah disampaikan guru, maka guru pertumbuhan dan perkembangan dapat menilai kemampuan anak dalam peserta didik kearah yang lebih baik bercerita dilihat dari lafalnya lagi.

\section{Menetapkan}

Rancangan

Penilaian Kegiatan Bercerita.

Rancangan penilaian ini mengacu pada rancangan pelaksanaan kegiatan, serta tujuan dan tema yang telah dipilih sebelumnya. Berkenaan dengan tema menabung, guru dapat menggali pengalaman anak berkaitan dengan kebiasaan anak dalam menabung atau apa yang akan mereka lakukan dengan uang tabungan mereka serta apa yang akan mereka lakukan jika menemui orang yang dalam kesulitan serta membutuhkan uang segera. Tanggapan dan jawaban mereka merupakan petunjuk atas pemahaman mereka atas isi cerita.

Sesuai hasil wawancara dengan beberapa informan diperoleh informasi bahwa: Kegiatan penilaian selalu guru lakukan pada setiap kegiatan pembelajaran. Demikian pula halnya pada kegiatan bercerita. Dengan memberi kesempatan kepada anak untuk bercerita kembali cerita yang (kemampuan mengucap bunyi/huruf), kosa kata (perbendaharaan), struktur (kemampuan mengucap kalimat sesuai dengan SPOK), isi pembicaraan (isi cerita)

\section{D.KESIMPULAN :}

Hasil penelitian menunjukkan bahwa penerapan strategi pembelajaran bercerita oleh guru pada anak-anak kelompok B dari segi : menetapkan tema dan tujuan, menetapkan bentuk bercerita yang dipilih, menetapkan bahan dan alat yang diperlukan dalam kegiatan bercerita, menetapkan rancangan langkah-langkah kegiatan bercerita, menetapkan rancangan penilaian kegiatan bercerita, telah dilaksanakan dengan baik. Walaupun masih terdapat kekurangan-kekurangan. Namun guru merusaha meminimalisir kekurangan tersebut demi perkembangan anak yang optimal.

\section{REFERENSI}


Bachtiar S bachri, 2005.

Pengembangan Kegiatan

Bercerita Di Taman Kanak-

Kanak, Teknik Dan Prosedurnya,

Jakarta Dekdiknas Dirjen Dikti

Direktorat Pembinaan

Pendidikan Tenaga

Kependidikan Dan Ketenagaan

Perguruan Tinggi

Masitoh, dkk. 2005, strategi pembelajaran TK Jakarta Pusat Penerbitan Universitas Terbuka

Muh. Nur Mustakin, 2005. Peranan

Cerita Dalam Pembentukan

Perkembangan Anak Tk Jakarta

Depdiknas Direktorat Jenderal

Pendidikan Tinggi, Direktorat

Pembinaan Tenaga

Kependidikan Dan Ketenagaan

Perguruan Tinggi

Tadkiroatun musfiroh 2005. Bercerita

Untuk Anak Usia Dini, Jakarta

Depdiknas, Dirjen Dikti,

Direktorat Pembinaan

Pendidikan Tenaga

Kependidikan Dan

Ketenagaan Perguruan Tinggi 